\title{
Prevalence and factors associated with exposure to sunlight and sunscreen among physical education teachers in Pelotas, southern Brazil*
}

\author{
Airton José Rombaldi ${ }^{1}$ \\ Marilda Borges Neutzling ${ }^{2}$
}

\author{
Lúcio Kerber Canabarro ${ }^{1}$ \\ Marcelo Cozzensa da Silva ${ }^{1}$
}

DOI: http:/ / dx.doi.org/10.1590/abd1806-4841.20175821

\begin{abstract}
BACKGROUND: Decreasing the time of exposure to the sun and increasing sunscreen use are important actions to prevent skin cancer.

Овлестіvе: This study aimed to verify the prevalence of exposure to the sun and the use of sunscreen, as well as associated factors among physical education teachers of the basic education network from city of Pelotas, southern Brazil.

Methods: A census type study was conducted with physical education teachers of the basic education network from Pelotas. This study assessed the time of exposure to the sun in the workplace for at least $20 \mathrm{~min}$, between $10 \mathrm{am}$ and $4 \mathrm{pm}$, and the use of sunscreen during the workday.

RESULTS: 188 teachers answered the questionnaire. The prevalence of exposure to the sun between 10:00am and 4:00pm was $89.2 \%$ (95\% CI of $83.8 \%-93.3 \%$ ), while sunscreen use was $63.3 \%$ (95\% CI of $56.0 \%-70.2 \%)$. However, when the sample was stratified by sex, women reported a higher rate of sunscreen use $(78.5 \%-95 \% \mathrm{CI}$ of $72.2-84.3)$ than men $(38.9 \%-95 \% \mathrm{CI}$ of 31.8-46.2) $(\mathrm{p}<0.001)$. Teachers with longer work weeks were at greater risk of exposure to the sun. In addition, women, with normal weight and who worked less hours, were more likely to use sunscreen.

STUDY LIMITATIONS: Cross-sectional study and lack of information on the proper use and frequency of use of sunscreen.

CONCLUSION: Physical education teachers were highly exposed to solar radiation, and less than two-thirds used sunscreen during the workday. Interventions with this professional group are necessary to reduce the risk of skin cancer.
\end{abstract}

Keywords: Melanoma; Occupational Cancer; Work; Sunlight

\section{INTRODUCTION}

One's field of work can represent a risk factor for certain diseases. ${ }^{1}$ Professionals in the field of education, especially teachers, appear to be the most exposed to diseases related to vocal problems, repetitive movement lesions, allergies, and emotional disturbances. ${ }^{2-4}$ In addition, those who work outdoors, such as physical education teachers, are highly exposed to ultraviolet radiation and have a greater risk of developing skin cancer. ${ }^{5,6}$

Skin cancer is a disease of multifactorial etiology, resulting primarily from genetic alterations, environmental factors, and lifestyles. ${ }^{7}$ The most important prevalence of skin cancers falls within diseases from basal cell carcinomas (far and away the most com- mon), to squamous cell carcinoma, and finally to melanomas. ${ }^{8}$

The non-melanoma cancer is the most common in Brazil and corresponds to $25 \%$ of all malignant tumors in the country, with the estimate from 2012 recording more than 134,000 new cases in Brazil. On the other hand, melanoma cancer represents $4 \%$ of malignant skin neoplasia, but it is the most severe due to the occurrence of metastasis. In 2010, approximately 1,500 deaths occurred, resulting from each of the types of cancer. ${ }^{9}$ In Brazil, the occurrence of skin cancer has been growing, especially in the southeastern and southern regions of the country, due to multiple epidemiological factors, including an exaggerated exposure to the sun. ${ }^{8}$

Received on 20.03.2016.

Approved by the Advisory Board and accepted for publication on 01.08.2016.

* Study carried out at the Universidade Federal de Pelotas (UFPel) - Pelotas (RS), Brasil.

Financial support: None

Conflict of interest: None.

Sports Department, Universidade Federal de Pelotas (UFPel), Pelotas, RS, Brazil.

Nutrition Department, Universidade Federal do Rio Grande do Sul (UFRGS), Porto Alegre, RS, Brazil.

(C)2017 by Anais Brasileiros de Dermatologia 
On the other hand, the exposure to ultraviolet rays can be attenuated with the use of sunscreens, hats, sunglasses, and exposure during appropriate times of the day. Thus, sunscreens are not only cosmetic, but also effective protectors against solar radiation in many situations. ${ }^{10}$

In Brazil, in 2003, according to the latest INEP survey, 60,000 teachers were working in physical education courses in the basic education network, 5,000 of which in the state of Rio Grande do Sul, an expressive number that calls for studies that can guide specific policies geared toward the improvement and/or prevention of diseases and illnesses. ${ }^{11}$ In this sense, understanding their behavior regarding their exposure to the sun and the use of sunscreen in this at-risk group is necessary in order to enable specific and effective interventions.

Taking into account the small quantity of national and international studies on the subject and the inexistence of national population studies, the present investigation aimed to verify the time of exposure to the sun and the use of sunscreen among physical education teachers in basic education in the city of Pelotas, southern Brazil. ${ }^{12-16}$

\section{METHODS}

This was an observational, cross-sectional, and census-guided study. One hundred twelve basic education schools in the urban zone of the city of Pelotas, which were determined to be eligible for the study, were contacted. In order to conduct this research in the aforementioned educational institutions, we requested authorization from the city's Department of Education, responsible for the local public schools, and from the $5^{\text {th }}$ Regional Coordination Education Offices, in charge of the state and private schools. Together with the request for authorization to conduct the study, the listing of all existing schools in the urban zone of Pelotas was requested. This document served as a foundation to guide data collection.

Demographic, socioeconomic, behavioral, nutritional, health, and work related characteristics were obtained by means of a standardized questionnaire containing 53 questions. The age variable was collected in a continuous manner and, in the analysis, was placed into categories of decades (20-30; 31-40; 41-50; > 50 years). The interviewed participants were questioned as to their smoking habit and those who had smoked at least one cigarette in the last 30 days were considered smokers (the variable was categorized as "never smoked", "ex-smoker", and "smoker"). One's self-reported perception of health was measured by the question: "How do you consider your health?" The answer possibilities were: (1) excellent, (2) very good, (3) good, (4) not bad, and (5) poor.

The Brazilian economic classification criterion from the Brazilian Association of Research Companies (categorized in the consumption classes of A [highest] and B/C) was used as a socioeconomic indicator. ${ }^{17}$ The level of physical activity during a normal work week was measured by applying the leisure section of the long version of the International Physical Activity Questionnaire (IPAQ). ${ }^{18}$ The score was calculated in the following manner: minutes per week walking + minutes per week of moderate physical exercise $+($ minutes per week of vigorous physical exercise* 2). ${ }^{19}$ A cut-off point of 150 minutes per week was used to classify the subjects as active or insufficiently active. ${ }^{20}$ The nutritional status was determined by the body mass index (BMI), calculated by verifying the self-reported weight and height, and was classified according to WHO criteria. ${ }^{21}$

The independent variables related to work were "time of work at the school (years)", collected in a continuous manner and categorized in decades; "weekly work shift (hours)", collected in a continuous manner and categorized in 10-20h, 21-40h, > 41h; "education network where the teacher works", categorized as public, private, and both; and "completed post-graduate course", categorized as yes or no.

The results from the present study were times of exposure to the sun, collected by the question: "approximately how much time are you exposed to the sun daily between 10:00am and 4:00pm, during your workday at school?" (the answers were offered in hours and minutes/day and were later categorized in up to 20 minutes/ day and more than 20 minutes/day of exposure to the sun), and the use of sunscreen, measured by the question: ${ }^{22}$ "Do you usually use sunscreen during your workday?" (the answer possibilities were "(1) Yes" and "(2) No"). This outcome was dichotomized into individuals who have never used sunscreen and those who reported using it, regardless of how often they used it. A third variable of interest was measured by the question: "Do you usually use a cap/ hat/ similar protection during your workday?", with the answer options of "(1) Yes" and "(2) No".

The questionnaires were self-reported under the supervision of a trained interviewer, with $98.9 \%$ filled out in the school environment. Exceptionally, the location of collection was another workplace (gym clubs) or at the teacher's home. Educators were considered eligible for this study if they were working as a basic education school teachers during the period of data collection. Those who were working exclusively in administrative functions, in other non-teaching functions, or on leave for whatever reason were excluded from the study. The information of the number of physical education teachers who worked at the school was supplied by the school's director or pedagogical coordinator and, when in doubt, the teacher's time card was consulted. Refusals were those teachers who, at least two times, verbally expressed their desire not to participate in the study within a minimum interval of one week.

The interviewers were undergraduate students from the courses of Nutrition and Physical Education from the Federal University of Pelotas. The students went through 12 hours of training. These research assistants helped participants to understand the questionnaire and assisted in case of doubts about how to fill out the form. Ten percent of the interviewed subjects were selected to maintain quality control, which was performed via telephone contacts with teachers and through visits to the schools.

All of the participants signed the term of free and clear consent, and the research was approved by the Ethics Committee of the Physical Education Faculty of the Federal University of Pelotas, logged under protocol number 032/2009.

The data bank was set up in the Epi-Info 6.0 software, with each questionnaire being entered twice so as to verify any typing errors. To analyze the data, the Stata software, version 12.0, was used. A descriptive analysis of the subjects, in terms of socioeconomic, demographic, behavioral, health, and work variables, was used. The 
bivariate analysis performed by comparing the outcomes and the independent variables was tested by means of chi-square tests for heterogeneity and linear tendency. The multivariate analysis was conducted by the Poisson regression with robust variance. ${ }^{23}$ In the analysis, all of the variables that presented the value of $p \leq 0.2$ in the crude analysis for confusion control were maintained. The level of significance was set at $5 \%$.

\section{RESULTS}

The number of physical education teachers who worked in both public and private networks in basic education in the urban zone of Pelotas was 212. Of these, 188 answered the questionnaire, a fact that represents a rate of answers of $88.7 \%$. The independent variable with a largest number of ignored values was "Weekly work shift", in which 18 individuals did not inform their weekly work hours.

The majority of individuals were female $(61.7 \%)$, between 31 and 50 years of age $(70.3 \%)$, and belonged to the B/C socioeconomic levels (68.6\%). More than three fourths had never smoked, $62.6 \%$ perceived their health as excellent and very good, $60.9 \%$ were eutrophic, and $56.4 \%$ were sufficiently active in their leisure-time activities (Table 1).

Almost all of the interviewed individuals (97.3\%) had a university degree in physical education, and $55.4 \%$ had concluded a post-graduate course (of which, $87,1 \%$ were specializations, $11.9 \%$ were Masters degrees, and $1.0 \%$ were Ph.D.). Table 2 shows that the majority of teachers presented up to 20 years of work in the school environment (71.9\%), exercised a total weekly work shift of up to 40 hours $(75.7 \%)$ and worked in the public education network $(77.1 \%)$.

The prevalence of teachers that reported being exposed to the sun between 10:00am and 4:00pm, for more than 20 minutes was $89.2 \%$ (95\% CI of 83.8-93.3), and the frequency of use of sunscreen was $63.3 \%$ (95\% CI from 56.0-70.2). However, when the sample was stratified by sex, women reported a greater use of sunscreen (78.5\% - 95\% CI from 72.2-84.3) than the men (38.9\% - 95\% CI from 31.8-46.2) $(\mathrm{p}<0.001)$ (Table 2).

Table 3 presents the crude and adjusted prevalence ratios, between the outcome "exposure to the sun in the period between 10:00am and 4:00 pm" and independent variables. The sole variable that remained associated with the outcome in the adjusted analysis was the variable of weekly work shift, with the teachers with a work week of greater than 40 hours presented a $40 \%$ higher risk of being exposed to solar radiation.

Table 4 shows the crude and adjusted prevalence ratios between the outcome "the use of sunscreen" and independent variables. The variables associated with the outcome after the adjustment were sex (with women presenting $100 \%$ more probability of using sunscreen), the BMI (overweight and obese individuals with

\begin{tabular}{|c|c|c|c|c|c|c|}
\hline \multirow[t]{2}{*}{ Variables } & \multicolumn{2}{|c|}{ Men } & \multicolumn{2}{|c|}{ Women } & \multicolumn{2}{|c|}{ Total } \\
\hline & $\mathrm{N}$ & $\%$ & $\mathrm{n}$ & $\%$ & $\mathrm{n}$ & $\%$ \\
\hline \multicolumn{7}{|l|}{ Age (years) } \\
\hline $20-30$ & 17 & 23.6 & 16 & 13.8 & 33 & 17.5 \\
\hline $31-40$ & 18 & 25.0 & 40 & 34.5 & 58 & 30.9 \\
\hline $41-50$ & 26 & 36.1 & 48 & 41.4 & 74 & 39.4 \\
\hline$>50$ & 11 & 15.3 & 12 & 10.3 & 23 & 12.2 \\
\hline \multicolumn{7}{|l|}{ Economic level (ABEP)* } \\
\hline A (highest) & 25 & 34.7 & 34 & 29.3 & 59 & 31.4 \\
\hline $\mathrm{B} / \mathrm{C}$ & 47 & 65.3 & 82 & 70.7 & 129 & 68.6 \\
\hline \multicolumn{7}{|l|}{ Smoking } \\
\hline Smoker & 4 & 5.6 & 12 & 10.4 & 16 & 8.6 \\
\hline Ex-smoker & 7 & 9.9 & 17 & 14.8 & 24 & 12.9 \\
\hline Never smoked & 60 & 84.5 & 86 & 74.8 & 146 & 78.5 \\
\hline \multicolumn{7}{|l|}{ Self-reported health } \\
\hline Excellent & 18 & 25.0 & 17 & 14.8 & 35 & 18.7 \\
\hline Very good & 27 & 37.5 & 55 & 47.8 & 82 & 43.9 \\
\hline Good & 22 & 30.6 & 40 & 34.8 & 62 & 33.2 \\
\hline Not bad/Bad & 5 & 6.9 & 3 & 2.6 & 8 & 4.2 \\
\hline \multicolumn{7}{|l|}{ BMI $\left(\mathrm{kg} / \mathrm{m}^{2}\right)^{* *}$} \\
\hline Eutrophic & 28 & 38.9 & 84 & 75.00 & 112 & 60.9 \\
\hline Overweight & 37 & 51.4 & 21 & 18.8 & 58 & 31.5 \\
\hline Obese & 7 & 9.7 & 7 & 6.2 & 14 & 7.6 \\
\hline \multicolumn{7}{|c|}{ Physical activity in leisure (min/week)\& } \\
\hline Insufficiently active & 25 & 34.7 & 56 & 49.1 & 81 & 43.6 \\
\hline Active & 47 & 65.3 & 58 & 50.9 & 105 & 56.4 \\
\hline
\end{tabular}

${ }^{*} \mathrm{ABEP}=$ Brazilian Association of Research Companies; ${ }^{* *} \mathrm{BMI}=$ Body Mass Index; ${ }^{\star}$ min/week = minutes per week. 
TABLE 2: Description of the population of Physical Education Teachers from the basic education network in Pelotas, southern Brazil, according to variables of occupation and exposure to the sun $(n=188)$

\begin{tabular}{|c|c|c|c|c|c|c|}
\hline \multirow[t]{2}{*}{ Variables } & \multicolumn{2}{|c|}{ Men } & \multicolumn{2}{|c|}{ Women } & \multicolumn{2}{|c|}{ Total } \\
\hline & $\mathrm{n}$ & $\%$ & $\mathrm{n}$ & $\%$ & $\mathrm{~N}$ & $\%$ \\
\hline \multicolumn{7}{|c|}{ Time of work at the school (years) } \\
\hline$<10$ & 35 & 49.3 & 39 & 43.0 & 84 & 45.4 \\
\hline $11-20$ & 16 & 22.5 & 33 & 29.9 & 49 & 26.5 \\
\hline$>21$ & 20 & 28.2 & 32 & 28.1 & 52 & 28.1 \\
\hline \multicolumn{7}{|c|}{ Work week (hours)* } \\
\hline Up to 20 & 16 & 23.9 & 26 & 24.5 & 42 & 24.3 \\
\hline $21-40$ & 28 & 41.8 & 61 & 57.6 & 89 & 51.4 \\
\hline$\geq 41$ & 23 & 34.3 & 19 & 17.9 & 42 & 24.3 \\
\hline \multicolumn{7}{|c|}{ Education Network where the teacher works } \\
\hline Public & 48 & 66.7 & 97 & 83.6 & 145 & 77.1 \\
\hline Private & 13 & 18.0 & 6 & 5.2 & 19 & 10.1 \\
\hline Both & 11 & 15.3 & 13 & 11.2 & 24 & 12.8 \\
\hline \multicolumn{7}{|c|}{ Completed post-graduate course } \\
\hline Yes & 32 & 45.7 & 71 & 61.2 & 103 & 55.4 \\
\hline No & 38 & 54.3 & 45 & 38.8 & 83 & 44.6 \\
\hline \multicolumn{7}{|c|}{$\begin{array}{l}\text { Exposed to the sun from } 10: 00 \mathrm{am} \text { to } 4: 00 \mathrm{pm} \\
\text { for at least } 20 \text { minutes }\end{array}$} \\
\hline Yes & 64 & 90.1 & 101 & 88.6 & 165 & 89.2 \\
\hline No & 7 & 9.9 & 13 & 11.4 & 20 & 10.8 \\
\hline \multicolumn{7}{|c|}{ Uses sunscreen } \\
\hline Yes & 28 & 38.9 & 91 & 78.5 & 119 & 63.3 \\
\hline No & 44 & 61.1 & 25 & 21.6 & 69 & 36.7 \\
\hline
\end{tabular}

*Variable with the highest number of missing individuals $(\mathrm{n}=18)$

$10 \%$ and $50 \%$ more probability, respectively, of not using sunscreen), and the weekly work shift (teachers with a work week of between 21 and 40 hours showed $10 \%$ more probability of not protecting themselves with sunscreen).

The association between the use of protection against solar radiation in the form of caps/hats/ similar protection and the variable of age and sex of teachers is presented in figure 1. It was observed that there was a statistically significant linear tendency $(p<0.05)$ of the reduction of the use of protection as men grew older.

\section{DISCUSSION}

Regarding the present study, it should be emphasized its census nature and the low index of losses and refusals (11.3\%). However, some limitations also need to be considered: cross-sectional study, as well as the lack of information about the correct use and the frequency of sunscreen use.

It was observed that nearly $90 \%$ of the interviewed individuals reported being exposed to the sun daily for between 10:00am and 4:00pm for more than 20 minutes. These results run in line with studies $^{7,12-15,24-27}$ that indicated that the problem of excessive exposure to the sun was an important professional risk factor. The high prevalence of exposure to the sun reported in the present study was also observed in studies ${ }^{13,27,28}$ conducted in Brazil, which revealed the frequencies of exposure to the sun of $69.5 \%$ in physical education teachers, in both sexes, who worked in water activities in the city of Rio de Janeiro; of $85.5 \%$ in active individuals of 15 years of age or more from 15 Brazilian capitals and the Federal District of Brasilia; and of $60.4 \%$ in students, from both sexes, from high schools in the countryside of Rio Grande do Sul. ${ }^{13,27,29}$ Reports of intense solar radiation suffered by physical education teachers were observed in Australia and in the United States. ${ }^{14,29}$ One possible explanation for the high prevalence of exposure to the sun verified in the present study may well be the fact that the majority of teachers work in the public education network. These institutions receive a low level of investment, with no covered or thermally comfortable spaces for physical education classes. ${ }^{24-26}$

Less than two thirds (63.3\%) of the interviewed individuals used sunscreen regularly during their workday. However, when the teachers were stratified by sex, the frequency of use by women (78.5\%) was two times greater than the number of male sunscreen users. The prevalence of the use of sunscreen was slightly less than the frequency of use reported in the literature by youth of both sexes - high school students from the countryside of Rio Grande do Sul (74.3\%) - and much higher than the percentages reported in studies conducted with physical education teachers who teach water sports (17.9\%) and individuals of 15 years of age or more who live in 15 Brazilian capitals and the Federal District of Brasilia (23.0\%). ${ }^{13,27,28}$ Although the prevalence of sunscreen use is substantially higher than in some studies, nearly $36.7 \%$ of the teachers from the present study did not protect themselves from solar radiation and subjected themselves to a high risk of developing skin cancer. ${ }^{13,27}$ 
TABLE 3: Association of independent variables with exposure to the sun in the period between 10:00am and 4:00pm in Physical Education Teachers from the basic education network in Pelotas, southern Brazil ( $n=188)$

Variables
Prevalence of exposure to the sun $>20 \mathrm{~min} / \mathrm{day}$

n

\section{Sex}

Male

Female

Age (years)

20-30

31-40

41-50

$>50$

Economic level

A (highest)

B/C

Smoking

Smoker

Ex-smoker

Never smoked

Self-reported health

Excellent

Very good

Good

Not bad/Bad

BMI (kg/m2)\#

Eutrophic

Overweight

Obese

Time worked at the school (years)

Up to 10

$11-20$

$>20$

Work week (hours)

Up to 20

21-40

$>40$

Education network where the teacher works

Public

Private

Both

Completed post-graduate course

Yes

No

$\%$

\section{1}

97

23

53

63

20

47

111

\section{1}

13

20

124

27

68

56

7

94

49

11

78.6

$67 \quad 79.8$

45

44

30

74

41

124

12

22

87

70
90.1

88.6

71.9

91.2

86.3

87.0

81.0

87.4

81.3

83.3

86.1

79.4

84.0

90.3

87.5

85.5

86.0

78.6

94.0

86.3

71.4

84.1

100.0

87.3

63.2

91.7

86.1

85.4

Crude PR Adjusted PR

P-value $(95 \% \mathrm{CI}) \quad(95 \% \mathrm{CI})^{\mathrm{a}}$

1.0

$1.0(0.9-1.1)$

$$
\begin{array}{cc}
0.8(0.6-1.1) & 0.9(0.7-1.2) \\
1.0(0.9-1.3) & 1.1(0.9-1.3) \\
1.0(0.8-1.2) & 1.0(0.8-1.2) \\
1.0 & 1.0
\end{array}
$$

1.0

$1.0(0.9-1.2)$

1.0

$1.0(0.8-1.4)$

$1.1(0.8-1.4)$

$0.9(0.7-1.2)$

$1.0(0.7-1.3)$

$1.1(0.8-1.4)$

1.0

1.0

$1.0(0.9-1.1)$

$0.9(0.7-1.2)$

1.0

1.0

$1.2(1.0-1.3) \quad 1.1(0.9-1.3)$

$1.1(0.9-1.3) \quad 1.0(0.8-1.3)$

$<0.001^{* 2}$

1.0

$1.2(1.0-1.5)$

1.0

$1.2(0.9-1.5)$

$1.4(1.2-1.8)$

$0.2^{* 2}$

1.0

$0.7(0.5-1.0)$

1.0

$0.7(0.5-1.1)$

$1.0(0.8-1.1)$

$0.8^{\star 2}$

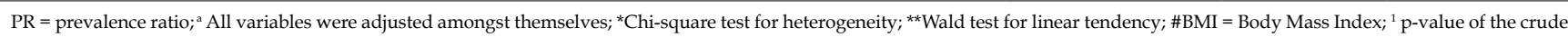
analysis; ${ }^{2}$-value of the adjusted analysis.

Regarding the outcome "time exposed to the sun between 10:00am and 4:00pm daily", the variable that continued to be associated after the adjusted analysis was the "weekly work shift", given that the teachers with a work week of greater than 40 hours presented a $40 \%$ higher risk of being exposed to solar radiation. The verified association can be explained by the increase in the time of solar radiation due to an increase in the work week of the basic education school teachers. Similar results were also found in other Brazilian studies. ${ }^{30,31}$
The variables that remained associated with the outcome "the use of solar protection" were sex (women presented 100\% higher probability of using solar protection) and BMI (overweight and obese individuals presented $10 \%$ and $50 \%$ greater probability, respectively, of not using solar protection). The results of the present study, indicating that the women more frequently use sunscreen, are corroborated by the literature. ${ }^{13,27,28,32}$ The female vanity and the concerns related to the esthetic and health questions may well justify 
TABLE 4: Association of the sociodemographic, behavioral, nutritional, health, and work related variables with the use of sunscreen in Physical Education Teachers from the basic education network in Pelotas, southern Brazil $(n=188)$

\begin{tabular}{|c|c|c|c|c|c|}
\hline \multirow[t]{2}{*}{ Variables } & \multicolumn{2}{|c|}{ Prevalence of of sunscreen use } & \multirow{2}{*}{$\begin{array}{c}\text { Crude PR } \\
(95 \% \text { CI })\end{array}$} & \multirow{2}{*}{$\begin{array}{c}\text { Adjusted PR } \\
(95 \% \mathrm{CI})^{\mathrm{a}}\end{array}$} & \multirow[t]{2}{*}{ P-value } \\
\hline & $\mathbf{n}$ & $\%$ & & & \\
\hline Sex & & & & & $<0.001^{* 2}$ \\
\hline Male & 28 & 38.9 & 1.0 &..-- & \\
\hline Female & 91 & 78.5 & $1.0(0.9-1.1)$ & & \\
\hline Age (years) & & & & & $0.6^{* 2}$ \\
\hline $20-30$ & 16 & 48.5 & $0.8(0.6-1.1)$ & $0.9(0.7-1.2)$ & \\
\hline $31-40$ & 41 & 70.7 & $1.0(0.9-1.3)$ & $1.1(0.9-1.3)$ & \\
\hline $41-50$ & 51 & 68.9 & $1.0(0.8-1.2)$ & $1.0(0.8-1.2)$ & \\
\hline$>50$ & 11 & 47.8 & 1.0 & 1.0 & \\
\hline Economic level & & & & & $0.3^{*_{1}}$ \\
\hline A (highest) & 34 & 57.6 & 1.0 &.$--\cdot$ & \\
\hline $\mathrm{B} / \mathrm{C}$ & 85 & 65.9 & $1.0(0.9-1.2)$ & & \\
\hline Smoking & & & & & $0.9^{* 1}$ \\
\hline Smoker & 10 & 62.5 & 1.0 & -.-.- & \\
\hline Ex-smoker & 16 & 66.7 & $1.0(0.8-1.4)$ & & \\
\hline Never smoked & 91 & 62.3 & $1.1(0.8-1.4)$ & & \\
\hline Self-reported health & & & & & $0.3^{* 2}$ \\
\hline Excellent & 20 & 57.1 & $0.9(0.7-1.2)$ & & \\
\hline Very good & 58 & 70.3 & $1.0(0.7-1.3)$ & & \\
\hline Good & 37 & 59.7 & $1.1(0.8-1.4)$ & & \\
\hline Not bad/Bad & 3 & 37.5 & 1.0 &..--- & \\
\hline BMI $\left(\mathrm{kg} / \mathrm{gm}^{2}\right) \#$ & & & & & $0.001^{* * 2}$ \\
\hline Eutrophic & 81 & 72.3 & 1.0 & -.-.- & \\
\hline Overweight & 30 & 51.7 & $1.0(0.9-1.1)$ & & \\
\hline Obese & 15 & 35.7 & $0.9(0.7-1.2)$ & & \\
\hline Time worked at the school (years) & & & & & $0.5^{* 2}$ \\
\hline Up to 10 & 50 & 59.5 & 1.0 & 1.0 & \\
\hline $11-20$ & 38 & 77.6 & $1.2(1.0-1.3)$ & $1.1(0.9-1.3)$ & \\
\hline$>20$ & 29 & 55.8 & $1.1(0.9-1.3)$ & $1.0(0.8-1.3)$ & \\
\hline Work week (hours) & & & & & $0.05^{\star 2}$ \\
\hline Up to 20 & 22 & 52.4 & 1.0 & 1.0 & \\
\hline $21-40$ & 61 & 68.5 & $1.2(1.0-1.5)$ & $1.2(0.9-1.5)$ & \\
\hline$>40$ & 27 & 64.3 & $1.4(1.2-1.7)$ & $1.4(1.2-1.8)$ & \\
\hline Education network where the teacher works & & & & & $0.3^{* 2}$ \\
\hline Public & 97 & 66.9 & 1.0 & 1.0 & \\
\hline Private & 8 & 42.1 & $0.7(0.5-1.0)$ & $0.7(0.5-1.1)$ & \\
\hline Both & 14 & 58.3 & $1.1(0.9-1.2)$ & $1.0(0.8-1.1)$ & \\
\hline Completed post-graduate course & & & & & $0.2^{* 2}$ \\
\hline Yes & 75 & 72.8 & 1.0 & 1.0 & \\
\hline No & 44 & 53.0 & $1.0(0.8-1.1)$ & $0.9(0.8-1.0)$ & \\
\hline
\end{tabular}

$\mathrm{PR}=$ prevalence ratio; ${ }^{a}$ All variables were adjusted amongst themselves; ${ }^{*}$ Chi-square test for heterogeneity; ${ }^{* *}$ Wald test for linear tendency; \#BMI = Body Mass Index; ${ }^{1} \mathrm{p}$-value of the crude analysis; ${ }^{2}$ p-value of the adjusted analysis.

the greater prophylactic behavior among women. ${ }^{28}$ Individuals with a higher BMI tend to present a lower use of sunscreen.

Although many studies do not present associations with the nutritional status, the finding can be explained by the greater quantity of sunscreen necessary to cover body parts of more overweight and obese individuals, which implies a greater expense, which can in turn compromise a teacher's salary. ${ }^{27,32-34}$ Duquia et al. ${ }^{22}$ corroborate this result when they report, in a study conducted with the population of Pelotas, that the use of sunscreen was connected to socioeconomic variables. Moreover, risky behavior also seems to be associated, and those people who have already presented factors for chronic diseases (being overweight or obese) fall within another risk factor (less use of sunscreen) for another disease, skin cancer. ${ }^{35}$

As regards the use of another type of protection against solar radiation (such a caps/hats/other similar protection), the present risk demonstrated that men, as they grow older, present a 

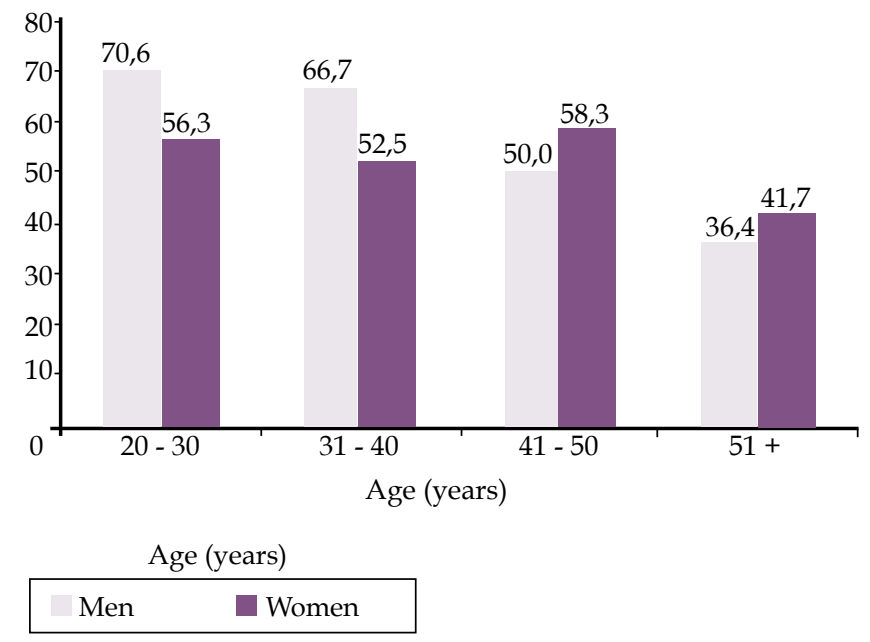

Figure 1: Association between cap/hat/similar protection and the variables of age and sex of the Physical Education Teachers from the basic education network in Pelotas, southern Brazil $(n=188)$ tendency to reduce the use of sunscreen. This result is hard to explain, as it would contradict the consulted literature, which shows no difference among the age ranges nor reveals that the older individuals are more compliant with protection methods. ${ }^{27,31,36}$ It can be speculated that the causes of this tendency are the lack of regular use and neglect, given that men seem to be less concerned about questions of esthetics.

\section{CONCLUSION}

It could be concluded that the physical education teachers from the public and private education networks from the city of Pelotas, southern Brazil, were highly exposed to solar radiation during their workdays, and at least two thirds used sunscreen during the workday, with women more often following this habit. The workday proved to be associated with exposure to the sun, and the age and BMI variables were associated with the teachers' use of sunscreen. Interventions with this professional group are necessary to reduce the risk of skin cancer.

\section{REFERENCES}

1. Brasil. Ministério da Saúde do Brasil. Organização Pan-Americana da Saúde no Brasil. Doenças relacionadas ao trabalho: manual de procedimentos para os serviços de saúde. Brasília: Ministério da Saúde do Brasil; 2001. 580 p. (Série A. Normas e Manuais Técnicos; n. ${ }^{0}$ 114).

2. Delcor NS, Araújo TM, Reis EJ, Porto LA, Carvalho FM, Oliveira e Silva M, et al. Condições de trabalho e saúde dos professores da rede particular de ensino de Vitória da Conquista, Bahia, Brasil. Cad. Saúde Pública. 2004;20:187-96.

3. Gasparini SM, Barreto SM, Assunção AA. Prevalência de transtornos mentais comuns em professores da rede municipal de Belo Horizonte, Minas Gerais, Brasil. Cad. Saúde Pública. 2006;22:2679-91.

4. Porto LAR, Reis IC, Andrade JM, Nascimento RB, Carvalho FM. Doenças ocupacionais em professores atendidos pelo centro de estudos da saúde do trabalhador. Rev. Baiana Saúde Pública. 2004;2833-49.

5. Glanz K, Buller DB, Saraiya M. Reducing ultraviolet radiation exposure among outdoor workers: state of the evidence and recommendations. Environ Health. 2007 Aug 8;6:22.

6. Sbdri.org.br [Internet]. Lima RB. Profissões que aumentam o risco de câncer de pele. Rio de Janeiro: Sociedade Brasileira de Dermatologia - Regional Rio de Janeiro, 2007. [acesso 30 abr 2013]. Disponível em: http://www.sbdrj.org.br/ dicas/dicas_profissoes_que_aumentam_o_risco_de_cancer_de_pele.asp.

7. Popim RC, Corrente JE, Marino JAG, Souza CA. Câncer de pele: uso de medidas preventivas e perfil demográfico de um grupo de risco na cidade de Botucatu. Ciênc Saúde Colet. 2008;13:1331-6.

8. Ferreira FG, Nascimento LFC, Rotta 0. Fatores de risco para câncer da pele Nomelanoma em Taubaté, SP: um estudo caso-controle. Rev Assoc Med Bras. 2011:57:431-7.

9. Instituto Nacional de Câncer José Alencar Gomes da Silva. Coordenação Geral de Ações Estratégicas. Coordenação de Prevenção e Vigilância. Estimativa 2012: incidência de câncer no Brasil. Rio de Janeiro: Inca; 2011. 118 p.

10. Souza SRP, Fischer FM, Souza JMP. Bronzeamento e risco de melanoma cutâneo: revisão da literatura. Rev Saúde Pública. 2004;38:588-98.

11. Inep.gov.br [Internet]. Instituto Nacional de Estudos e Pesquisas Educacionais Anísio Teixeira. Censo dos profissionais do magistério da educação básica, 2003. Brasília: Ministério da Educação, 2006. [acesso 30 abr 2013]. Disponível em: http://portal.inep.gov.br/profissionais-do-magisterio.
12. Palma A, Azevedo APG, Ribeiro SSM, Santos TF, Nogueira L. Saúde e trabalho dos professores de educação física que atuam com atividades aquáticas. Arq Mov. 2006;2:81-101.

13. Oliveira LM, Glauss N, Palma A. Habits related to sun exposure among physical education teachers working with water activities. An Bras Dermatol. 2011;86:445-50.

14. Vishvakarman D, Wong JC, Boreham BW. Annual occupational exposure to ultraviolet radiation in Central Queensland. Health Phys. 2001;81:536-44.

15. Lazarov A, Nevo K, Pardo A, Froom P. Self-reported skin disease in hydrotherapists working in swimming pools. Contact Dermatitis. 2005;53:327-31.

16. Geller AC, Glanz K, Shigaki D, Isnec MR, Sun T, Maddock J. Impact of skin cancer prevention on outdoor aquatic staff: the Pool Cool program in Hawaii and Massachusetts. Prev Med. 2001;33:155-61.

17. Abep.org [Internet]. Associação Brasileira de Empresas de Pesquisa. Critério de classificação econômica Brasil 2009. [acesso 1 abr 2009]. Disponível em: http:// www.abep.org/novo/CMS/Utils/FileGenerate.ashx?id=46.

18. Craig CL, Marshall AL, Sjöström M, Bauman AE, Booth ML, Ainsworth BE, et al. International Physical Activity Questionnaire: 12-country reliability and validity. Med Sci Sports Exerc. 2003;35:1381-95.

19. Hallal PC, Victora CG, Wells JC, Lima RC. Physical inactivity: prevalence and associated variables in Brazilian adults. Med Sci Sports Exerc. 2003;35:1894-900.

20. Health.gov [Internet]. US Department of Health and Human Services. 2008 Physical Activity Guidelines for Americans. [cited 2009 Sep 29]. Available from: http://www.health.gov/paguidelines/pdf/paguide.pdf.

21. World Health Organization. Physical status: the use and interpretation of anthropometry: report of a WHO Expert Committee. Geneva: World Health Organization; 1995. (WHO Technical Report Series, 854).

22. Duquia RP, Baptista Menezes AM, Reichert FF, de Almeida HL Jr. Prevalence and associated factors with sunscreen use in southern Brazil: a population-based study. J Am Acad Dermatol. 2007;57:73-80.

23. Barros AJ, Hirakata VN. Alternatives for logistic regression in cross-sectional studies: an empirical comparison of models that directly estimate the prevalence ratio. BMC Med Res Methodol. 2003;3:21. 
24. Santini J, Molina Neto V. A síndrome do esgotamento profissional em professores de educação física: um estudo na rede municipal de ensino de Porto Alegre. Rev Bras Educ Fis Esp. 2005;19:209-22.

25. Silva JVP, Nunez PRM. Qualidade de vida, perfil demográfico e profissional de professores de educação física. Pensar Prat. 2009;12:1-11.

26. Gaspari TC, Souza Junior 0, Maciel V, Impolcetto F, Venâncio L, Rosário LF, et al. A realidade dos professores de educação física na escola: suas dificuldades e sugestões. Rev Min Ed Fis. 2006;14:109-37.

27. Szklo AS, Almeida LM, Figueiredo V, Lozana Jde A, Azevedo e Silva Mendonça G, Moura Ld, et al. Comportamento relativo à exposição e proteção solar na populacão de 15 anos ou mais de 15 capitais brasileiras e Distrito Federal, 20022003. Cad Saúde Pública. 2007;23:823-34.

28. Dupont L, Pereira DN. Sun exposure and sun protection habits in high school students from a city south of the country. An Bras Dermatol. 2012;87:90-5.

29. Kirsner RS, Parker DF, Brathwaite N, Thomas A, Tejada F, Trapido EJ. Sun protection policies in Miami-Dade County public schools: opportunities for skin cancer prevention. Pediatr Dermatol. 2005;22:513-9.

30. Lucena EES, Costa DCB, Silveira EJD, Lima KC. Prevalência de lesões labiais em trabalhadores de praia e fatores associados. Rev Saúde Pública. 2012;46:1051-7.

31. Rocha FP, Menezes AMB, Almeida Junior HL, Tomasi E. Marcadores e fatores de risco para queratoses actínicas e carcinomas basocelulares: um estudo de casocontrole. An Bras Dermatol. 2004;79:441-54.

32. Rizzatti K, Schneider IJC, d'Orsi E. Perfil epidemiológico dos cidadãos de Florianópolis quanto à exposição solar. Epidemiol Serv Saúde. 2011;20:459-69.

33. Hall HI, Jones SE, Saraiya M. Prevalence and correlates of sunscreen use among US high school students. J Sch Health. 2001;71:453-7.

34. Duffy SA, Choi SH, Hollern R, Ronis DL. Factors associated with risky sun exposure behaviors among operating engineers. Am J Ind Med. 2012;55:786-92.

35. Schuit AJ, van Loon AJ, Tijhuis M, Ocké M. Clustering of lifestyle risk factors in a general adult population. Prev Med. 2002;35:219-24.

36. Hora C, Batista CVC, Guimarães PB, Siqueira R, Martins S. Avaliação do conhecimento quanto à prevenção do câncer da pele e sua relação com exposição solar em frequentadores de academia de ginástica, em Recife. An Bras Dermatol. 2003;78:693-701.
MAILING ADDRESS:

Airton José Rombaldi

Rua Luís de Camões - 625

Bairro Três Vendas

96055-630 Pelotas, RS.

Brazil

E-mail: ajrombaldi@gmail.com

How to cite this article: Rombaldi AJ, Canabarro LK, Neutzling MB, Silva MC. Prevalence and factors associated with exposure to sunlight and sunscreen among physical education teachers in Pelotas, southern Brazil. An Bras Dermatol. 2017;92(6): 785-92. 